\title{
The influence of McKenzie's method in the treatment of low back pain
}

\author{
Vanessa Paula de Sousa', David Reis Moura', Francisco Valmor Macedo da Cunha',2
}

\begin{abstract}
Introduction: Low back pain, due to the high prevalence, is the main reason for sickness and pensions in Brazil causing a major burden for the state and the reduction of the individual's quality of life. The treatment may be conservative (drug and therapy) or surgery, but often such treatments are not definitive and culminating in reincidivas. Among the physiotherapy intervention techniques, Mckenzie method stands out because it is an individualized intervention technique that emphasizes patient education through exercises to restore normal function, where the patient learns to avoid during treatment movements, postures and activities that worsen your condition. Objective: This study aimed to investigate the effect of Mckenzie method on the treatment of lumbar. Methods: We performed a literature search of articles published between 2005 to 2015, in Portuguese, English and French, using the key words low back pain, quality of life and physical therapy in Scienciedirect databases, Peter, Pubmed, LILACS and scielo. Results and conclusion: The articles were initially screened for the content of the titles and abstracts and confronted the inclusion and exclusion criteria. Subsequently, the selected articles were analyzed in all content and data were organized into figures and framework to present the main findings of the research. Publications on the theme revealed the importance of McKenzie in the reduction of pain symptoms and disability in low back pain, contributing to the patient's return in their activities of daily living.
\end{abstract}

Keywords: Low back pain. Pain relief and physical therapy.

\section{INTRODUCTION}

Lumbar pain (LP) is a clinical condition that affects the region between the lumbar vertebrae, which may or may not radiate to the lower limbs, and affects individuals of both genders and age. It is the most common cause of activity limitation among people under the age of $45.1,2$

When associated with preexisting causal factors such as inflammatory, degenerative diseases, congenital defects, neoplasms, muscular weakness and rheumatic predisposition. Lumbar pain may become chronic and, therefore, incapacitating which leads to a decrease in the quality of life, a restriction in AVD'S and in work activity. ${ }^{3,4}$

About $50 \%$ to $80 \%$ of the population will be affected by low back pain at some stage of life, causing problems in public health, becoming the main cause of illness in Brazil, and the third cause of retirement due to disability, causing a socioeconomic impact. .5

People with low back pain feel unable to perform bending and twisting movements of the trunk, lifting loads and repetitive efforts without triggering a painful situation and, thus, causing an inability to perform activities at work and daily life, collaborating in making the chronic disease. About
$16.4 \%$ to $73.3 \%$ of patients with chronic low back pain manifest psychological disorders such as depression, anxiety, disability and dissatisfaction even at work and in social life. . $^{7,8,9}$

There are two types of classification for low back pain: the specific, which occurs when there is a cause, which can be caused by intrinsic factors such as degenerative, inflammatory, infectious and postural mechanics and extrinsic factors such as imbalance between functional load, effort in work activity and daily life activities. And unspecific, which may be termed idiopathic low back pain, or do not have a definite cause. ${ }^{10}$

In view of the large number of people who experience lower back pain (LP), physical therapy intervention helps to reduce or extinguish the pain, allowing the patient to return to daily activities. Among the resources used in physiotherapy for the pain relief and consequently to reduce disability are: electrothermotherapy, kinesiotherapy, muscle rebalancing techniques such as global postural reeducation (GPR), pilates and the Mckenzie Method. ${ }^{11}$

The Mckenzie Method is a noninvasive and reliable technique for assessing and managing patients with low back pain, besides to influencing in the fear and behavior. Patients

AUTHOR CORRESPONDING: Francisco Valmor Macedo Cunha Mail. Federal University of Piaui, Mauricio de Nassau Faculty and Faculty of Piaui (FAPI), Brazil.

E-mail: orfeuyeuridice@yahoo.com.br

${ }^{1}$ Faculdade do Piauí (FAPI), Teresina (PI), Brasil.

2 Faculdade do Piauí (FAPI), Maurício de Nassau, São Luís (MA), Brasil.

Financial support: There was no financial support for this study. 
are instructed to report their symptoms, intensity and location of pain as soon as they achieve a specific posture or repeat spinal movements. ${ }^{12,13}$

The overall goal of the McKenzie Method is that the patient perform a self-management which includes three considerable steps: explaining to patients the effects of final positions and movements and the implications of opposing and postural movements; to instruct on how to conserve the reduction and extinguish their symptoms; and teach the patient to repair lumbar spine function without reoccurring the symptoms. ${ }^{12}$

Based on the effects achieved by the method, for the treatment of low back pain, there is a decrease in the physical incapacity which is caused by pain, in addition to being an individualized treatment and lower cost for the patient. ${ }^{12}$

Thus, this study aimed to evaluate the effectiveness of the Mckenzie Method in the reduction of pain in patients with low back pain, through scientific publications in the physiotherapy area with the purpose of favoring the physiotherapist's clinical practice on the subject.

\section{METHODS}

This is a review of the literature about the Mckenzie Method in the treatment of low back pain. For the purpose, it was searched for articles in the databases Scielo, Scienciedirect, PEDro, Pubmed and LILACS, from 2005 to 2015 using the descriptors: "Low back pain, quality of life, Mckenzie Method and physiotherapy, in Portuguese, English, Spanish and French" available in full-text for reading.

It was selected publications which scope included the use of the McKenzie Method for the treatment of low back pain; Published in the years 2005 to 2015; Available in full-text for reading. The initial screening was performed based on the abstracts, and the articles that did not fit the inclusion criteria were excluded from the study because they were review articles, articles from the years before 2005, articles that involved impairment which prevented any physical therapy intervention for the spine, pregnant women and cervicalgia.

The found and selected publications, according to established criteria were organized in a research organization as shown in figure 1. and separated by year of publications as evidenced in figure 2., showing that the number of publications doubled in the last three years despite still representing a number relatively small of articles and by a table describing the used studies.

\section{RESULTS}

The electronic search in the databases, through the association of the descriptors Mckenzie Method with low back pain. 79 scientific articles were selected as shown in Figure 1. Demonstrating how screening and selection of articles were performed.

The analysis in Table 1 shows that most of the studies investigated if there was a reduction in symptoms and physical disability in patients with low back pain treated by the McKenzie Method. Regarding to subjects, it was composed of patients with pain of both genres with pain complaints.

\section{DISCUSSION}

In 1956, Robin McKenzie created a method that has expanded because of the way it evaluates, treats and prevents spinal problems, through two components: the educational which gives to the patient an understanding of his problem and the benefit of movement in his rehabilitation; and the active mechanical therapy component which consist in exercises prescribed by the physiotherapist based on the assessment. ${ }^{12}$

However, there is a lack of structured reviews with details of the articles selected and their analysis, which include not only the description of the technique, but also demonstrate

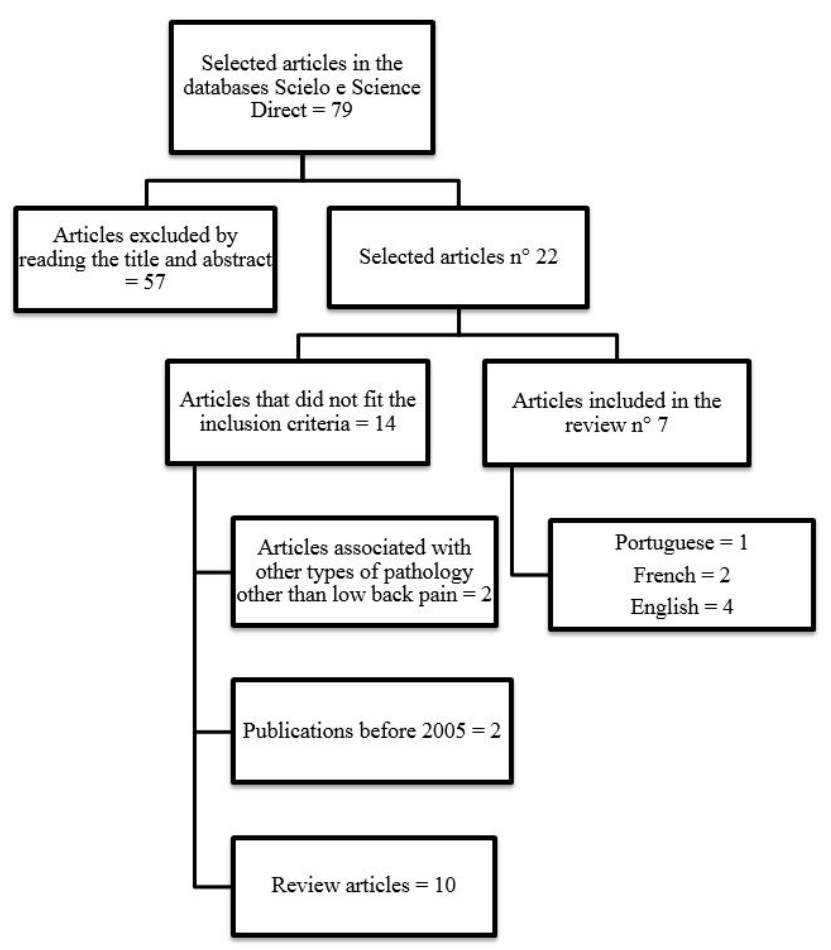

Figure 1. Research organization chart: Screening and selection of articles.

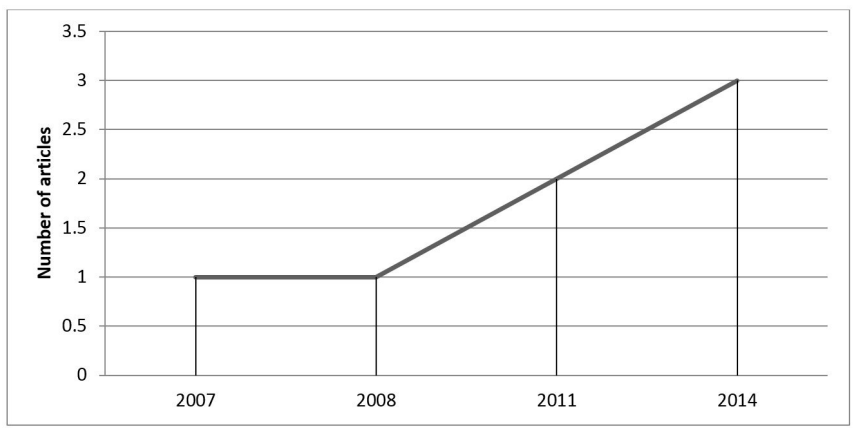

Figure 2. Distribution of publications according to the year of research. 
Table 1. Description of studies published between the years 2005-2015 related to the McKenzie Method and low back pain. Legend: ROM: Range of motion; IL4: interleukin four; NRS: Pain Numerical Rating Scale

\begin{tabular}{|c|c|c|c|c|}
\hline Author and Year & Objective & Subject Type & Method & Outcome / Conclusion \\
\hline $\begin{array}{l}\text { Clare et al. } \\
(2007)^{14}\end{array}$ & $\begin{array}{l}\text { Investigate if the McKenzie } \\
\text { extension procedure improves low } \\
\text { back pain. }\end{array}$ & $\begin{array}{l}50 \text { patients with low } \\
\text { back pain classified in } \\
\text { the disarrangement } \\
\text { and non-disarray } \\
\text { syndrome. }\end{array}$ & $\begin{array}{l}\text { They were treated with extension } \\
\text { procedure and was measured } \\
\text { at two positions, standing and } \\
\text { prone. Three methods were } \\
\text { used, inclinometer, Schober and } \\
\text { tip of the finger to the ground. } \\
\text { Measurements were taken in a } \\
\text { random order. }\end{array}$ & $\begin{array}{l}\text { Patients in the disarrangement } \\
\text { syndrome achieved a significantly } \\
\text { greater improvement in spine } \\
\text { length and reported a higher } \\
\text { perception of recovery than those } \\
\text { classified as non-disarrangement. }\end{array}$ \\
\hline $\begin{array}{l}\text { Paatelma, et al., } \\
(2008)^{15} \text {. }\end{array}$ & $\begin{array}{l}\text { To compare the methods of } \\
\text { Orthopedic Manual Therapy } \\
\text { (OMT), McKenzie Method and } \\
\text { Guidance. }\end{array}$ & $\begin{array}{l}134 \text { patients with } \\
\text { acute, chronic and } \\
\text { recurrent low back } \\
\text { pain. }\end{array}$ & $\begin{array}{l}\text { They were divided into } 3 \text { groups. } \\
45 \text { in the OMT group, } 52 \text { in the } \\
\text { McKenzie Method and } 37 \text { in the } \\
\text { orientation group to remain active } \\
\text { and avoid rest. }\end{array}$ & $\begin{array}{l}\text { The Mckenzie method did not } \\
\text { result in better results compared to } \\
\text { orthopedic physiotherapy }\end{array}$ \\
\hline $\begin{array}{l}\text { Al-Obaidi, et al., } \\
(2011)^{12} \text {. }\end{array}$ & $\begin{array}{l}\text { Understanding the bio-behavioral } \\
\text { characteristics and physical } \\
\text { performance in individuals } \\
\text { with chronic low back pain who } \\
\text { manifested centralized pain } \\
\text { phenomenon and received the } \\
\text { McKenzie intervention. }\end{array}$ & $\begin{array}{l}62 \text { volunteers with } \\
\text { chronic low back } \\
\text { pain, } 28 \text { males and } 34 \\
\text { females. }\end{array}$ & $\begin{array}{l}\text { They passed a Mckenzie } \\
\text { assessment and completed } \\
\text { questionnaires related to pain, fear } \\
\text { and incapacity. }\end{array}$ & $\begin{array}{l}\text { McKenzie reduced pain, physical } \\
\text { disability, and fear. In addition to } \\
\text { improving physical performance. }\end{array}$ \\
\hline $\begin{array}{l}\text { Garcia, et al, } \\
(2011)^{16} .\end{array}$ & $\begin{array}{l}\text { To analyze the efficacy of Back } \\
\text { School and Mckenzie Methods in } \\
\text { patients with non-specific chronic } \\
\text { low back pain in relation to pain } \\
\text { intensity, functional performance } \\
\text { and range of motion (ROM) for } \\
\text { spinal flexion. }\end{array}$ & $\begin{array}{l}14 \text { women and } 4 \\
\text { men with chronic low } \\
\text { back pain totaling } \\
18 \text { volunteers. }\end{array}$ & $\begin{array}{l}\text { Four evaluation instruments } \\
\text { were used: evaluation form, Pain } \\
\text { Numerical Rating Scale (NRS), } \\
\text { Roland Morris Disability and } \\
\text { fleximeter. }\end{array}$ & $\begin{array}{l}\text { Both the McKenzie Method and } \\
\text { the Back School Method decreased } \\
\text { the pain and improved functional } \\
\text { performance, but there was no } \\
\text { difference in ROM of spinal flexion. }\end{array}$ \\
\hline $\begin{array}{l}\text { Bonnet, et al, } \\
(2014)^{17} \text {. }\end{array}$ & $\begin{array}{l}\text { To evaluate the short-term } \\
\text { treatment of non-specific low back } \\
\text { pain using directional preference. }\end{array}$ & $\begin{array}{l}54 \text { patients with low } \\
\text { back pain. }\end{array}$ & $\begin{array}{l}\text { Participants were divided into two } \\
\text { groups one being treated with the } \\
\text { Mckenzie Method and the other } \\
\text { usual care. }\end{array}$ & $\begin{array}{l}\text { Directional preference altered the } \\
\text { location of pain in patients with } \\
\text { irradiated pain, but there was no } \\
\text { significant improvement in pain } \\
\text { intensity and functional disability. }\end{array}$ \\
\hline $\begin{array}{l}\text { Saud } \\
\text { Al-Obaidi, et al., } \\
(2014)^{18}\end{array}$ & $\begin{array}{l}\text { Observe the immune responses } \\
\text { after } 4 \text { weeks of intervention with } \\
\text { McKenzie in patients with acute } \\
\text { low back pain. }\end{array}$ & $\begin{array}{l}15 \text { patients with acute } \\
\text { low back pain. }\end{array}$ & $\begin{array}{l}10 \mathrm{ml} \text { of peripheral blood were } \\
\text { obtained from each patient at } \\
\text { the beginning and at the end of } \\
\text { the attendance, flow cytometric } \\
\text { analysis was used to evaluate } \\
\text { the amount of leukocytes from } \\
\text { CD4+ T lymphocytes and cytokine } \\
\text { subpopulations. }\end{array}$ & $\begin{array}{l}\text { Pain relief has been shown } \\
\text { to be due to the increase in } \\
\text { anti-inflammatory cytokines, IL4. }\end{array}$ \\
\hline $\begin{array}{l}\text { Machado LAC et } \\
\text { al, (2014) }\end{array}$ & $\begin{array}{l}\text { To verify if the Mckenzie Method } \\
\text { reduces the symptomatology } \\
\text { and the physical incapacity in } \\
\text { individuals with low back pain. }\end{array}$ & $\begin{array}{l}146 \text { patients aged } \\
18-80 \text { years with a } \\
\text { history of non-specific } \\
\text { low back pain. }\end{array}$ & $\begin{array}{l}\text { They were divided into two groups, } \\
73 \text { in the guideline group and } \\
73 \text { who received guidance with } \\
\text { McKenzie. }\end{array}$ & $\begin{array}{l}\text { It was found that the Mckenzie } \\
\text { Method in acute low back pain } \\
\text { did not show short-term clinical } \\
\text { improvement in pain, incapacity, } \\
\text { function or overall effect, however } \\
\text { it decreased the demand for } \\
\text { complementary care. }\end{array}$ \\
\hline
\end{tabular}

the effectiveness of this method in reducing pain and physical incapacity caused by the disease.

During mechanical evaluation of the spine with the McKenzie Method the patient may be classified into three syndromes: dysfunction, postural and disarray. The derangement syndrome is the most frequent and consists of the internal rupture of the fibrous annulus and displacement of the pulposus nucleus or adjacent soft tissues, resulting in pain and functional limitation. ${ }^{20}$
Mckenzie noted that patients with low back pain had a "directional preference" which improved pain including a centralizing component of pain for radiated pain, increased range of motion, and improved symptoms overall. ${ }^{21}$

Concerning the use of the method in different syndromes listed by Mckenzie, ${ }^{14}$ Clare et al. compared the effectiveness of the directional preference for extension in individuals with low back pain classified in the disarray and non-disarrangement syndrome (dysfunction and postural) for six months. The study 
showed that all 50 patients treated and evaluated improved symptomatology, however, the results were more prominent in the patients classified in the derangement syndrome with significant pain improvement and increased range of motion.

In another study, Bonet et al ${ }^{17}$. utilized the directional preference to treat individuals with low back pain distributed randomly in two groups: treated by the McKenzie Method and treated by the recommendations established by the National Health Authority (NHA). The first performed exercises with directional preference in the planes of flexion, extension, inclination or rotation. Each session lasted half an hour on average. The centralization of pain was observed in $62.5 \%$ of the patients, compared with $16.7 \%$ who used the recommendations established by NHA.

An important finding of the study Bonet et al ${ }^{17}$ is that the preferably directional, although it caused the centralized pain, resulted in no decrease in the intensity and physical disability. This finding was appointed by the authors as a result of the short period of treatment and suggest that positional preference techniques are more effective for long-term treatments which corroborates to the results found by Clare et al ${ }^{14}$. which treatment lasted six months.

Other studies have been concerned about showing the effectiveness of Mckenzie in relation to other techniques for the treatment of low back pain. Thus, LAC, et al ${ }^{19}$. In a sample of 146 participants divided into two groups: the first was oriented to home care, such as avoiding bed rest and paracetamol use; and the second group treated by the McKenzie method were instructed to perform pain-centering movements and postures as well as receiving a leaflet about back pain treatment which contained prescription exercises at home. After three months of the beginning of the programs, the patients were reevaluated and there was no significant difference between the groups regarding pain and decrease of physical disability. It should be noted that although there was no difference, the home care group used paracetamol throughout the treatment, and this did not give it an advantage over Mckenzie treatment.

Paatelma, et al ${ }^{15}$. in a sample of 134 patients with acute, chronic and recurrent low back pain, compared the effectiveness of Mckenzie in the treatment with orthopedic manual therapy (OMT) and guidance for home care. Pain level and physical disability were measured by the Visual Analogue Scale (VAS) and the Roland-Morris Point Scale. Both Mckenzie and OMT obtained significant improvement in less time than the orientation group.

Also in this sense, Garcia ${ }^{16}$ et al. compared the effectiveness of Mckenzie and the Back School technique in a sample of 18 volunteers with chronic low back pain. Patients were assessed for pain through VAS and functional performance using the Roland Morris scale. The Garcia et al ${ }^{16}$ findings corroborate the Paatelma et $\mathrm{a}^{15}$ where both groups used in the study shown to reduce the intensity of pain and physical disability caused by pathology.
Al-Obaidi et al ${ }^{12}$ conducted a prospective cohort study, on the 5th and 10th week after treatment it was carried out the measures of the results in order to compare the McKenzie method and motor control exercise in patients with chronic low back pain. For evaluation, it was applied Fear Avoidance Questionnaire surveys (FABQ) that evaluates the fear of physical activities and work, EVA for pain assessment and Roland Morris, besides the measuring of temporary physical performance usual walk, brisk walking, to sit and trunk flexion. The group treated by McKenzie obtained a significant reduction of pain, physical incapacity, and influence in the fear of these individuals when performing movements and irritative postures at the end of the 5 th week of treatment, remaining stable until the last evaluation.

Although it being mechanical manipulations and postures, the McKenzie technique has been shown to act much more than by such means including changes in production and release of anti-inflammatory cytokines as demonstrated by Al-Obaidi et al $^{18}$. In this study, in the fourth week of treatment with the McKenzie Method there is a significant increase of the anti-inflammatory cytokine IL-4 (interleukin 4) accompanied by low pain rates.

Finally, the research makes clear that the Mckenzie Method helps in reducing pain and decreases complementary care, allowing an improvement in the ability to cope with the disease and thus avoid recurrence.

\section{CONCLUSION}

The McKenzie Method works in a beneficial way in the treatment of low back pain, reducing pain and reducing the physical disability generated by the pathology, besides preventing recurrence. However, longer follow-up studies and samples as well as well-delineated diagnostic criteria are necessary for the populations are properly delimited and serve as a source for clinical decision making in the future.

\section{AUTHORS CONTRIBUTION}

Vanessa Paula de Sousa - Acted on selection and analysis of the article. David Reis Moura- Acted on selection and analysis of the article. Francisco Valmor Macedo da Cunha- Acted on selection and analysis of the article. Formatting and submission.

\section{COMPETING INTERESTS}

The authors have declared that no competing interests exist.

\section{REFERENCES}

1- Marques AP, Rhoden L, Siqueira JO, João SMA. Pain evaluation of patientswith fibromyalgia, osteoarthrits, and low back pain. Rev HospClinFacMedSão Paulo. 2001;56:5-10.

2- Weiner DK, Sakamoto S, Pereira S, et al. Chronic low back pain in older adults: prevalence, reliability, and validity of physical examination findings. J AM Geriatr Soc. 2006;54(1):11-20.

3- Silva MC, Fassa AG, Valle NCJ. Dor lombar crônica em uma população adulta do Sul do Brasil: prevalência e fatores associados. CadSaúde Pública. 2004; 20:377-85. 
4- Kent PM, Keating JL. The epidemiology of low back pain in primary care. ChiroprOsteopat. 2005;13:13.

5- Mancin B, Bonvicine G, Gonçalves C, Barboza MAI. Análise da influência do sedentarismo sobre a qualidade de vida de pacientes portadores de dor lombar crônica. ConScientiae Saúde. 2008;7(4):441-7

6- Ferreira MS, Navega MT. Efeitos de um programa de orientação para adultos com lombalgia. Acta Ortop Bras. 2010;18(3):127-31. doi:10.1590/ S1413- 78522010000300002.

7- Siqueira FB, Teixeira-Salmela LF, Magalhães LC. Análise das propriedades psicométricas da versão brasileira da Escala de Tampa de Cinesiofobia. ActaOrtop Bras. 2007;15(1):19-24

8- Fanian H, Ghassemi GR, Jourkar M, Mallik S, Mousavi MR. Psychological profile of Iranian patients with low-back pain. East Mediterr Health J. 2007;13(2):335-46.

9- Elkayam O, Ben Itzhak S, Avrahami E, Meidan Y, Doron N, Eldar I, Keidar I, LiramN, Yaron M. Multidisciplinary approach to chronic back pain: prognostic elements of the outcome. ClinExpRheumatol 14(3): 281-288, 1996.

10- Andrade SC, Araujo AGR, Vilar MJP. Escola de coluna": revisão histórica e sua aplicação,ao na lombalgia cronica. RevBrasReumatol. 2005;45:224-8.

11- Alfieri FM, Lopes-Silva HO, Laudugério GS, Souza KM, Rampini S, Salvanha F. Analise da funcionalidade, dor, flexibilidade e força muscular de portadores de lombalgia crônica submetidos a diferentes intervenções fisioterapêuticos. Rev. Fisioterapia Ser. 2008 [acesso 02 abr 2015]; 3 (2). Disponível em: https://www.mendeley.com/profiles/rodrigo-araujo6/ publications/?page $=1$.

12- Saud M. Al-Obaidi, PhD, Nowall A. Al-Sayegh, PhD, Huzaifa Ben Nakhi, FRCS, Mariam Al- Mandeel, PT.Evaluation of the McKenzie Intervention for Chronic Low Back Pain by Using Selected Physical and Bio-Behavioral Outcome Measures. 2011[acesso 2015 mar 17]; 3: 637-646. Disponível em: http://www.ncbi.nlm.nih.gov/pubmed/21777863.

13- Clare HA, Adams R, Maher CG. Reliability of McKenzie classification of patients with cervical or lumbar pain. J Manipulative PhysiolTher2005; 28: 122-127. Disponivel em: http://www.jmptonline.org/article/S01614754(05)00004-7/abstract
14- Helen A. Clarea, Roger Adams, Christopher G. Maher. Construct validity of lumbar extension measures in McKenzie's derangement syndrome. Manual Therapy[ online ] 2007 [ acesso 2015 jul 25]; 12: 328-334. Disponível em: http://www.manualtherapyjournal.com/article/S1356689X(06)00115-9/abstract

15- Paatelma Markku, MSc, PT, KilpikoskiSinikka, et al. Orthopaedic manual therapy, mckenzie method or advice only for low back pain in working adults: a randomized controlled trial with one year followup. J Rehabil Med [ on line ] 2008 [ acesso 2015 set 04 ]; 40: 858863. Disponívelem: http://www.medicaljournals.se/jrm/content/?d oi=10.2340/16501977-0262

16- Alessandra N. Garcia, rancine L.B. Gondo, Renata A. Costa, Fábio N. Cyrillo, Leonardo O. P. Costa. Efeitos de duas intervenções fisioterapêuticas em pacientes com dor lombar crônica não específica: viabilidade de um estudo controlado aleatorizado. RevBrasFisioter, [ online ] 2011 [ acesso 2015 ago 24];15(5):420-7.Disponível em http:// www.scielo.br/scielo.php?pid=S141335552011000500013\&script $=$ s ci_arttext\&tlng=pt

17- Bonnet Flavio, Monnet Sandrine, Otero Jacky. Effets à court terme d'un traitementselon la préférencedirectionnelle de patientslombalgiques. KinesitherRev[ online ] 2011 [ acesso 2015 set 04]; (112):51-59.

18- Saud Al-Obaidi, Fadia Mahmoud. Immune responses following McKenzie lumbar spine exercise in individuals with acute low back pain: A preliminary study. Acta Medica Academica [online] 2014 [acesso 2015 set 07]; 43(1): 19-29. Disponível em: http://ama.ba/index.php/ama/article/ view/204/pdf_34.

19- LAC Machado, et al. La méthodeMcKenzie n'apportepas d'amélioration clinique importante enplusdes soins habituelspourletraitement de lalombalgieaiguë. Kinesither Ver [ online ] 2014 [ acesso em 2015 set 06 ];14(151):15-16. Disponível em: http://www.em-consulte. com/article/906376/la-methode-mckenzie-n-apporte-pas-damelioration-c

20- McKenzie RA, May S. The lumbar spine: Mechanical diagnosis and therapy. 2nd ed. Waikanae (New Zealand) 7 Spinal Publications; 2003.

21- Kilpikoski S, Airaksinen O, MD, et al. Interexaminer Reliability of Low Back Pain Assessment Using the McKenzie Method. RevSpine [online] 2002 [acesso 13 mai 15]; 20 (8): E207-E214. Disponível em: http://www.udel. edu/PT/manal/spinecourse/mckenzie/McKenzie.pdf. 